\title{
PEMANFAATAN KEMASAN PRODUK SEBAGAI MEDIA PEMBELAJARAN MATEMATIKA MANIPULATIF
}

\author{
Dewi Nuur Rahmasari, M.Pd \\ E-Mail : dewi.rahmasari22@gmail.com
}

\begin{abstract}
ABSTRAK: Berbagai upaya dilakukan guna untuk meningkatkan kualitas pembelajaran di kelas. Tujuan penelitian ini adalah mengembangkan bahan ajar berupa lembar kerja siswa (LKS) pokok bahasan perbandingan berciri realistik berbantuan media kemasan produk,sehingga siswa dapat mengetahui secara langsung salah satu manfaat mempelajari materi perbandingan, serta membuat siswa terlibat aktif dalam proses pembelajaran. Model pengembangan mengacu pada model pengembangan Plomp, terdiri atas: (1) tahap investigasi awal, (2) tahap desain, (3) tahap realisasi/konstruksi, dan tahap (4) tahap tes, evaluasi, dan revisi, serta (5) implementasi.. Berdasarkan analisis pengembangan diperoleh hasil bahwa LKS yang dikembangkan dinyatakan valid, praktis, dan efektif
\end{abstract}

Kata Kunci : LKS, perbandingan, kemasan produk.

\section{A. PENGERTIAN MEDIA PEMBELAJARAN}

Kata media berasal dari bahasa Latin dan merupakan bentuk jamak dari kata medium yang secara harfiah berarti "perantara" atau "pengantar". AECT (Association of Education and Communication Technologi) memberi batasan tentang media sebagai segala bentuk dan saluran yang digunakan untuk menyampaikan pesan atau informasi ( dalam Arsyad, 2013:3). Sedangkan NEA (National Education Association) mengatakan media merupakan benda yang dimanipulasikan, dilihat, didengar, dibaca atau dibicarakan beserta instrumen yang dipergunakan dengan baik dalam kegiatan pembelajaran, dapat mempengaruhi efektifitas program instruksional (Sabri dalam Musfiqon,2011:27). Sementara itu, Suherman (2003:242) berpendapat bahwa media adalah suatu saluran untuk komunikasi. Menurut Suherman (2003:242) untuk memahami konsep abstrak siswa memerlukan benda-benda kongkrit sebagai perantara atau visualisasinya. Selanjutnya konsep abstrak yang baru dipahami siswa akan mengendap, melekat, dan tahan lama bila siswa belajar melalui perbuatan dan dapat dimengerti siswa, bukan sekedar mengingat. Selanjutnya, menurut Musfiqon (2011:28) media pembelajaran didefinisikan sebagai alat bantu berupa fisik maupun non fisik yang sengaja digunakan sebagai perantara antara guru dan siswa dalam memahami materi pelajaran.

Kegiatan pembelajaran yang efektif memerlukan suatu media yang mendukung. Media tersebut dapat berupa media manipulatif maupun media dengan bantuan teknologi. Menurut Sadiman (2002: 6) media adalah perantara atau 
pengantar pesan dari pengirim ke penerima pesan. Sedangkan menurut Brigs (dalam Sadiman, 2002: 6) media adalah segala alat fisik yang dapat menyajikan pesan serta merangsang siswa untuk belajar. Latuheru (dalam Hamdani: 2005) berpendapat bahwa media pembelajaran adalah bahan, alat atau teknik yang digunakan dalam kegiatan belajar mengajar dengan maksud agar proses interaksi komunikasi edukasi antara guru dan siswa dapat berlangsung secara tepat guna dan berdayaguna.

Berdasarkan pengertian-pengertian tersebut, dapat disimpulkan bahwa media pembelajaran merupakan segala sesuatu yang digunakan dalam kegiatan pembelajaran untuk menyampaikan materi dan informasi kepada siswa yang bertujuan merangsang pikiran, perasaan, minat dan perhatian siswa sehingga proses interaksi komunikasi edukasi antara guru (atau pembuat media) dan siswa dapat berlangsung secara tepat guna dan berdayaguna.

\section{B. MENGAPA MEDIA DIPERLUKAN DALAM PEMBELAJARAN MATEMATIKA}

Salah satu peranan media pembelajaran adalah mengoptimalkan seluruh panca indra siswa untuk mempermudah siswa belajar dengan langkah mendengar, melihat, meraba, serta menggunakan pikirannya dengan logis serta realistis. Pelajaran bukan hanya sekedar membayangkan secara abstrak, sehingga tujuan pemakaian media pembelajaranyaitu untuk mendemonstrasikan materi pelajaran yang abstrak ke didalam wujud visual. Tujuan media pembelajaran yang lain adalah sebagai berikut :
a. Sebagai alat bantu proses pembelajaran
b. Mempermudah proses pembelajaran di kelas
c. Meningkatkan efisiensi proses pembelajaran
d. Menjaga relevansi antara materi pelajaran dengan tujuan belajar
e. Membantu konsentrasi pembelajar dalam proses pembelajaran

Dengan demikian dapat disimpulkan tujuan dari adanya media pembelajaran adalah untuk menjembatani antara hal kongkrit dengan abstrak. Seperti saat guru matematika menggunakan model atau alat peraga untuk menjelaskan materi yang tidak dapat dipahami siswa hanya dengan membayangkannya saja. 
Selain tujuan dari penggunaan media pembelajaran, berikut akan dijabarkan beberapa contoh manfaat yang dapat kita lihat dari penggunaan media dalam pembelajaran:

1. Media pembelajaran dapat memberikan pengalaman tambahan, sehingga wawasan yang dimiliki para peserta belajar kurang lebih dapat disamakan.

2. Media pembelajaran dapat menyajikan informasi dari berbagai tempat.

3. Media pembelajaran dapat membangun interaksi..

4. Media pembelajaran dapat menciptakan proses penelitian. .

5. Media pembelajaran dapat dapat mempertahankan konsep mengajar secara utuh sekaligus nyata. Media kerap membantu pengajar untuk menjaga agar materi yang disampaikan tidak keluar dari ruang lingkup materi.

6. Media pembelajaran dapat menjadikan proses belajar mengajar lebih menarik sehingga meningkatkan motivasi belajar. Dengan memberikan variasi antara gambar, suara dan video, peserta belajar tidak akan merasa bosan.

7. Bahan pengajaran akan lebih jelas maknanya, sehingga dapat lebih di pahami pembelajar, serta memungkinkan pembelajar menguasai tujuan pengajaran dengan baik

8. Metode pembelajaran bervariasi, tidak semata-semata hanya komunikasi verbal melalui penuturan kata-kata lisan pengajar, pembelajar tidak bosan, dan pengajar tidak kehabisan tenaga.

9. Pembelajar lebih banyak melakukan kegiatan belajar, sebab tidak hanya mendengarkan penjelasa dari pengajar saja, tetapi juga aktivitas lain yang dilakukan seperti mengamati, melakukan, mendemonstrasikan dan lain-lainya.

10. Menciptakan kondisi dan situasi belajar tanpa tekanan.

\section{JENIS - JENIS MEDIA PEMBELAJARAN}

Media yang digunakan dalam pembelajaran beraneka ragam. Seseorang guru harus dapat memilih salah satu media pembelajaran yang akan digunakan. Penggunaan atau pemilihan media harus disesuaikan dengan materi dan tujuan pembelajaran yang akan dicapai

Menurut (Djamarah, 2002:140) menggolongkan media pembelajaran menjadi 
tiga yaitu:

1) Media auditif yaitu media yang mengandalkan kemampuan suara saja, seperti radio, kaset rekorder.

2) Media visual adalah media yang hanya mengandalkan indera penglihatan karena hanya menampilkan gambar diam seperti film bingkai, foto, gambar, atau lukisan.

3) Media audiovisual adalah media yang mempunyai unsur suara dan unsur gambar.

Selanjutnya (Sadiman, 2008:28) membagi media pembelajaran menjadi 3 golongan kelompok besar :

1) Media Grafis termasuk media visual seperti gambar/foto, sketsa, diagram, bagan/chart, grafik, kartun, poster, peta, dan globe.

2) Media Audio berkaitan dengan indera pendengaran. Seperti radio, alat perekam piata magnetik, piringan laboratorium bahasa

3) Media Proyeksi Diam seperti film bingkai (slide), film rangkai (film strip), media transparan, film, televisi, video.

Dari beberapa pendapat di atas, dapat disimpulkan bahwa jenis-jenis media pembelajaran sebagai berikut :

a Media Audio

Media Audio adalah media yang isi pesannya hanya diterima melalui indera pendengaran. Dilihat dari sifat pesan yang diterima, media audio dapat menyampaikan pesan verbal (bahasa lisan atau kata-kata) maupun non verbal (bunyi-bunyian dan vokalisasi).

b Media Visual

Media visual adalah media yang hanya mengandalkan indra penglihatan.

Media visual menampilan materialnya dengan menggunakan alat proyeksi atau proyektor, karena melalui media ini perangkat lunak (soft ware) yang melengkapi alat proyeksi ini akan dihasilkan suatu bias cahaya atau gambar yang sesuai dengan materi yang diinginkan.

c Media Audio-Visual

Media audio-visual disebaut juga sebagai media video. Video merupakan 
media yang digunakan untuk menyampaikan pesan pembelajaran. Dalam media video terdapat dua unsur yang saling bersatu yaitu audio dan visual. Adanya unsur audio memungkinkan siswa untuk dapat menerima pesan pembelajaran melalui pendengaran, sedangkan unsur visual memungkinkan penciptakan pesan belajar melalui bentuk visualisasi.

\section{FUNGSI MEDIA PEMBELAJARAN}

Dalam proses pembelajaran, media memiliki fungsi sebagai pembawa informasi dari sumber (guru) menuju penerima (siswa). Sedangkan metode adalah prosedur untuk membantu siswa dalam menerima dan mengolah informasi guna mencapai tujuan pembelajaran.

Dalam kegiatan interaksi antara siswa dengan lingkungan, fungsi media dapat diketahui berdasarkan adanya kelebihan media dan hambatan yang mungkin timbul dalam proses pembelajaran. Tiga kelebihan kemampuan media (Gerlach \& Ely dalam Ibrahim, et.al., 2001) adalah sebagai berikut. Pertama, kemapuan fiksatif, artinya dapat menangkap, menyimpan, dan menampilkan kembali suatu obyek atau kejadian. Dengan kemampuan ini, obyek atau kejadian dapat digambar, dipotret, direkam, difilmkan, kemudian dapat disimpan dan pada saat diperlukan dapat ditunjukkan dan diamati kembali seperti kejadian aslinya. Kedua, kemampuan manipulatif, artinya media dapat menampilkan kembali obyek atau kejadian dengan berbagai macam perubahan (manipulasi) sesuai keperluan, misalnya diubah ukurannya, kecepatannya, warnanya, serta dapat pula diulang-ulang penyajiannya. Ketiga, kemampuan distributif, artinya media mampu menjangkau audien yang besar jumlahnya dalam satu kali penyajian secara serempak, misalnya siaran TV atau Radio.

Media Pembelajaran berfungsi untuk merangsang pembelajaran dengan:

1. Menghadirkan obyek sebenarnya dan obyek yang langkah

2. Membuat duplikasi dari obyek yang sebenarnya

3. Mmembuat konsep abstrak ke konsep konkret 
4. Memberi kesamaan persepsi

5. Mengatasi hambatran waktu, tempat, jumlah, dan jarak

6. Menyajikan ulang informasi secara konsisten

7. Memberi suasana yang belajar yang tidak tertekan, santai, dan menarik.

Selain fungsi diatas. Livie dan Lentz(1982) mengemukakan 4 fungsi media pembelajaran yaitu:

a. Fungsi atensi berarti media visual merupakan inti, menarik dan mengrahkan perhatian pembelajar akan berkosentrasi pada isis pelajaran

b. Fungsi afekti maksudnya media visual dapat dilihat dari tingkat kenikmaran pembelajar ketika belajar membaca teks bergambar.

c. Fungsi kognitif yaitu mengungkapkan bahwa lambang visual mempelancar pencapaian tujuan dalam memahami dan mendengar informasi

d. Fungsi kompensatoris yaitu media visual memberikan konteks untuk memahami teks dan membantu pembelajr yang lemah dalam membaca untuk mengorganisasikan informasi dalam teks dan mengingatnya kembali.

Dari empat fungsi visual, dapat dikatakan bahwa belajar dari pesan visual memerlukan keterampilan tersendiri. tehnik afektif adalah tehnik untuk memahami tehnik pesan visual. yang terbagi dari beberapa fase seperti dibawah ini:

1. Fase diffrensiasi. yaitu dimana pembelajar mula-mula mengamati, mengidentifikasi dan menganalisis

2. Fase integrasi yaitu di mana mempelajar menempatkan unsure-unsur visual secara serempak, menghubungkan pesan-pesan visual kepada pengalaman pengalamannya.

3. Kesimpulan, yaitu dari pengalaman visualisai untuk kemudian menciptakan konseptualisasi baru dari apa yang mereka pelajari sebelumnya.

\section{E. Kemasan Produk Sebagai Media Pembelajaran}

Dalam pembelajaran matematika yang paling penting ditekankan adalah ketrampilan dalam proses berpikir.Peserta didik dilatih untuk dapat mengembangkan kemampuan berpikir logis, analitis, sistematis, dan konsisten. Untuk membantu dalam proses berpikir tersebut diperlukan alat bantu berupa media pembelajaran. Dengan adanya 
media pembeljararan diharapkan mampu menambah daya tarik bagi siswa dalam belajar. Sehingga pembelajaran matematika yang selama ini dianggap sangat "menakutkan" tidak lagi ada karena prosesnya diberikan secara menarik. Pembelajaran dengan menggunakan media kemasan produk sangat tepat untuk diimplemantasikan dalam pembelajaran matematika karena siswa dapat belajar memecahkan masalah dan mengembangkan penalarannya. Selain itu, siswa dapat mengetahui secara langsung salah satu maanfaat mempelajari materi perbandingan, serta membuat siswa terlibat aktif dalam proses pembelajaran.

Kemasan Produk merupakan salah satu media visual yang digunakan dalam proses pembelajaran secara berkelompok. Media ini diberikan pada pembelajaran bab perbandingan kelas 8 semester genap. Media ini dapat memperkuat konsep perbandingan yang telah siswa dapatkan,serta siswa dapat mengetahui secara langsung manfaat materi yang dipelajari dalam kehidupan sehari-hari melalui penggunaan media kemasan produk. Selain itu,media ini juga dapat membantu siswa lebih aktif dalam proses belajar karena terjadinya interaksi dengan siswa lain dan melatih kerjasamasehingga kesan belajar menjadi tidak membosankan dan bermakna.

Pada media ini dilengkapi dengan LKS yang menyajikan permasalahan kontekstual. Permasalahan kontekstual yang diberikan dekat dengan dunia siswa, sehingga siswa dapat merasakan langsung manfaat dari mempelajari materi perbandingan. LKS yang dikembangkan berisi pertanyaan atau langkah kegiatan agar siswa dapat menemukan konsep perbandingan senilai dan perbandingan berbalik nilai secara mandiri. LKS yang dikembangkan memiliki tampilan yang menarik, memuat gambar yang sesuai denganmateri, sehingga dimungkinkan siswa menjadi bersemangat dalam mempelajari materi perbandingan senilai. 


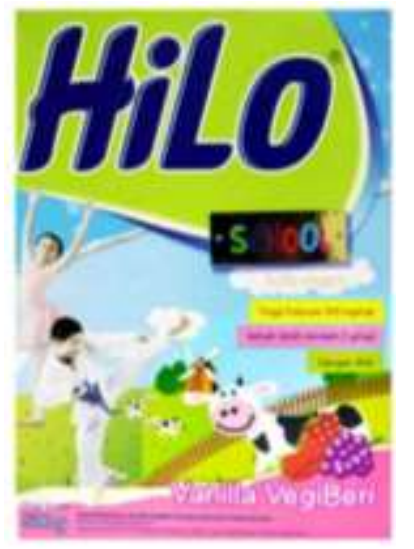

Gambar 1 Kemasan produk susu bubuk Frisian Flag

Dari gambar kemasan produk susu di atas dapat diketahui kandungan gizi yang terdapat dalam susu tersebut.

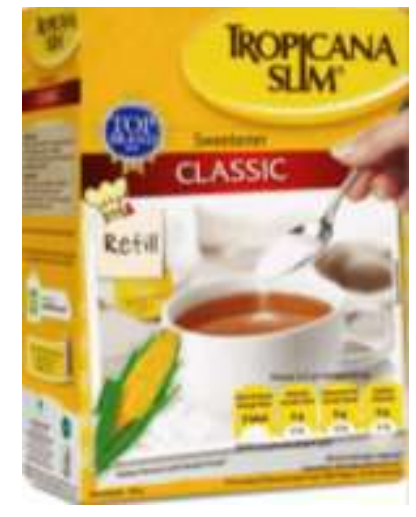

Gambar 2 Kemasan produkTropicana Slim

Terkait dengan materi perbandingan kemasan produk dapat digunakan dalam pembelajaran. Sebagai contoh pada gambar 2., Setiap hari Pak Rizal meminum secangkir teh dengan menggunakan gula "Tropicana Slim". Pada awal bulan Pak Rizal membeli gula “Tropicana Slim" dengan berat bersih (netto)250 gram. Di belakang kemasan produk terdapat informasi nilai gizi. Berapa hari yang diperlukan untuk menghabiskan satu kemasan gula “Tropicana Slim” 250 gram jika setiap hari pak Rizal meminum 2 cangkir teh ?. Permaslahan diatas dapat diselesaikan dengan menggunakan perbandingan senilai. 


\section{PEMBAHASAN}

\subsection{Kemasan Produk}

Menurut kurikulum 2013,materi perbandingan merupakan materi yang diajarkan pada siswa SMP kelas VIII semester genap. Kompetensi Dasar dari materi ini adalah :

4.2 Menggunakan konsep perbandingan untuk menyelesaikan masalah nyata dengan menggunakan tabel, grafik, dan persamaan.

Kemasan produk dapat digunakan untuk membantu memperkuat pemahaman siswa tentang materi Perbandingan.Materi hanya terbatas untuk sub materi perbandingan senilai mengingat keterbatasan waktu.

Media ini dibuat untuk meningkatkan pemahaman siswa tentang:

1. Menggunakan konsep perbandingan senilai untuk menyelesaikan masalah nyata dengan menggunakan tabel.

2. Siswa dapat menggunakan konsep perbandingan senilai untuk menyelesaikan masalah nyata dengan menggunakan grafik.

3. Siswa dapat menggunakan konsep perbandingan senilai untuk menyelesaikan masalah nyata dengan menggunakan persamaan.

\subsubsection{Hasil Simulasi}

2.3.1 Komentar dan Saran yang Sudah Dianalisis.

1. Fahrur Rozi: "Pada LKS ada soal yang menggunakan susu "Frisian Flag", padahal di soal cerita membahas susu "Hilo School", sebaiknya konsisten agar siswa tidak bingung ketika mengerjakan soal."

Tanggapan:

Saya menerima komentar ini, karena saya menyadari bahwa tulisan "Frisian Flag" pada soal belum diganti "Hilo School", karena memang pada awalnya ingin menggunakan kemasan produk "Frisian Flag", namun karena tidak ada, jadi diganti menggunakan kemasan produk susu "Hilo Scool".

2. Nurma: "Saya bingung, di LKS dipaparkan mengenai indikator yang ingin dicapai yaitu: Menjelaskan konsep perbandingan senilai dengan menggunakan tabel.Kemudian Menjelaskan konsep perbandingan senilai dengan 
menggunakan persamaan. Menurut saya, menjelaskan konsep perbandingan dengan menggunakan tabel dan persamaan belum kelihatan, malah cenderung penerapannya dalam kehidupan sehari-hari.

Tanggapan:

Saya menerima masukan dari saudara Nurma, karena media serta LKS lebih cenderung pada penerapan kehidupan nyata. Sehingga KD 3.12 yang semula digunakan diganti dengan $\mathrm{KD} 4.2$

3. M.Emsa : "Pada kegiatan Ayo Mengamati, di cerita ada pernyataan Rina ingin membeli susu ultramilk kemasan $200 \mathrm{ml}$ di supermarket dengan harga Rp3.000. Sebaiknya kata ingin jangan digunakan ,bagaimana jika Rina hanya ingin membeli, tidak benar-benar membeli susu tersebut?." Tanggapan:

Setelah saya cermati lagi, kata ingin memang seharusnya dihilangi agar tidak menimbulkan kerancuan dan salah tafsir.

4. Bapak Ery Hidayanto : "Apakah soal yang dibuat sudah benar-benar realistik?seperti untuk membuat 1 gelas susu "Hilo School" memerlukan 40 gram susu "Hilo School".

Tanggapan:

Iya Pak menurut saya sudah realistik, sesuai dengan aturan pada kemasan produk susu "Hilo School" terdapat keterangan untuk membuat 1 gelas susu "Hilo School" memerlukan 40 gram susu "Hilo School".

\subsection{Setelah Revisi}

\subsubsection{Hasil Revisi RPP}

Sebelum Revisi menggunakan KD 3.12, yaitu :

3.12 Memahami konsep perbandingan dengan menggunakan tabel, grafik, dan persamaaan. 


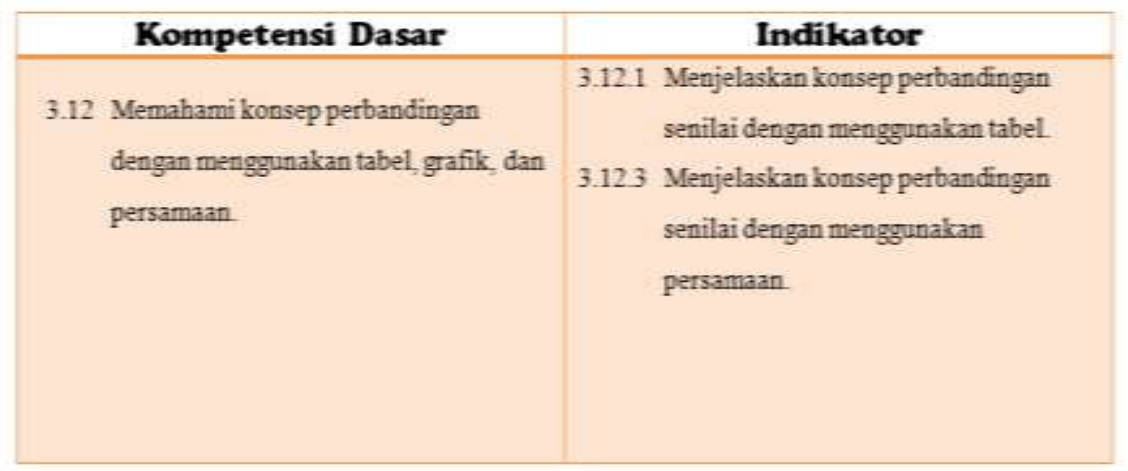

Setelah Revisi menggunakan KD 4.2, yaitu:

4.3 Menggunakan konsep perbandingan untuk menyelesaikan masalah nyata dengan menggunakan tabel, grafik, dan persamaan.

\begin{tabular}{|c|c|c|}
\hline Kompetensi Dasar & & Indikator \\
\hline $\begin{array}{l}\text { 4.2 Menggunakan konsep } \\
\text { perbandingan untuk menyelesaikan } \\
\text { masalah nyata dengan } \\
\text { menggunakan tabel, grafik dan } \\
\text { persamaan. }\end{array}$ & $\begin{array}{r}4.2 .3 \\
4.2 .5\end{array}$ & $\begin{array}{l}\text { Menggunakan konsep perbandingan } \\
\text { senilai untuk menyelesaikan masalah } \\
\text { nyata dengan menggunakan tabel. } \\
\text { Menggunakan konsep perbandingan } \\
\text { senilai untuk menyelesaikan masalah } \\
\text { nyata dengan menggunakan persamaan. } \\
\text { Menggunakan konsep perbandingan } \\
\text { senilai untuk menyelesaikan masalah } \\
\text { nyata dengan menggunakan grafik. }\end{array}$ \\
\hline
\end{tabular}

\subsubsection{Hasil Revisi Soal}

- Bagian Ayo Mengamati

Sebelum Revisi:

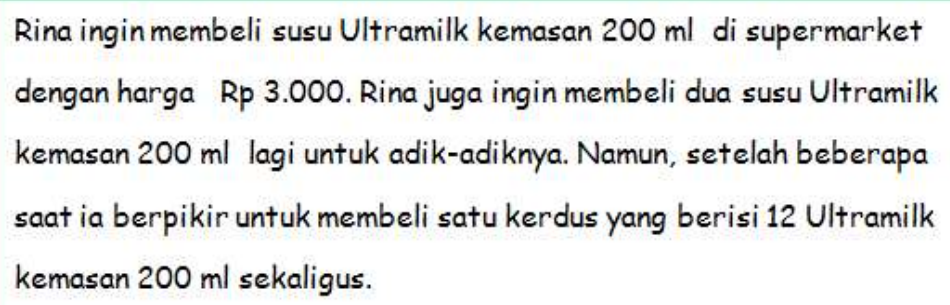

Setelah Revisi: 
Rina membeli susu Ultramilk kemasan $200 \mathrm{ml}$ di supermarket dengan harga Rp 3.000. Kemudian Rina juga membeli dua susu Ultramilk kemasan $200 \mathrm{ml}$ lagi untuk adik-adiknya. Namun, setelah beberapa saat berpikir, akhirnya ia membeli satu kerdus yang berisi 12 Ultramilk kemasan $200 \mathrm{ml}$ sekaligus.

- Bagian Ayo Berlatih

Sebelum Revisi:

Bu Sinta ingin membeli susu bubuk "Frisian Flag" kemasan 250 gram untuk persediaan selama 30 hari, maka berapa banyak kardus susu bubuk " $F$ " kemasan 250 gram yang harus dibeli Bu Sinta?

Setelah Revisi :

Bu Sinta ingin membeli susu bubuk "Hilo School" kemasan 250 gram untuk persediaan selama 30 hari, maka berapa banyak kardus susu bubuk "Hilo School" kemasan 250 gram yang harus dibeli Bu Sinta? 


\section{PENUTUP}

3.1 Harapan tentang kebermanfaatan media kemasan produk

Media ini diharapkan dapat menginspirasi pendidik untuk menggunakan media ini dalam pembelajaran Bab Perbandingan, karena media ini mudah didapatkan. Selain itu, media ini diharapkan dapat dikembangkan untuk materi atau konsep matematika lain karena permasalahan kontekstual adalah masalah yang dekat dengan kehidupan siswa,sehingga dapat melatih siswa terbiasa menyelesaikan masalah dikehidupan sehari-hari. Selain itu pembelajaran dengan media kemasan produk ini dapat membuat siswa menjadi lebih bersemangat saat belajar matematika, karena siswa dapat mengetahui secara langsung maanfaat materi yang dipelajari. 


\section{DAFTAR RUJUKAN}

Arsyad, A. 2013. Media Pembelajaran. Jakarta: Rajawali Press.

As'ari, A.R, dkk. 2014. Matematika SMP/MTs Kelas VIII Semester 2. Jakarta: Kementrian Pendidikan dan Kebudayaan.

Suherman, E. H., dkk. 2003. Strategi Pembelajaran Matematika Kontemporer. Bandung: JICA. 
